\title{
Konsep Dasar Media Pembelajaran
}

\author{
Juhaeni $^{1}$, Safaruddin ${ }^{2}$, R. Nurhayati ${ }^{3}$ Aulia Nur Tanzila ${ }^{4}$ \\ 1,3 Universitas Islam Negeri Sunan Ampel, Surabaya, Indonesia \\ 2,3 IAIM Sinjai, Sinjai, Indonesia
}

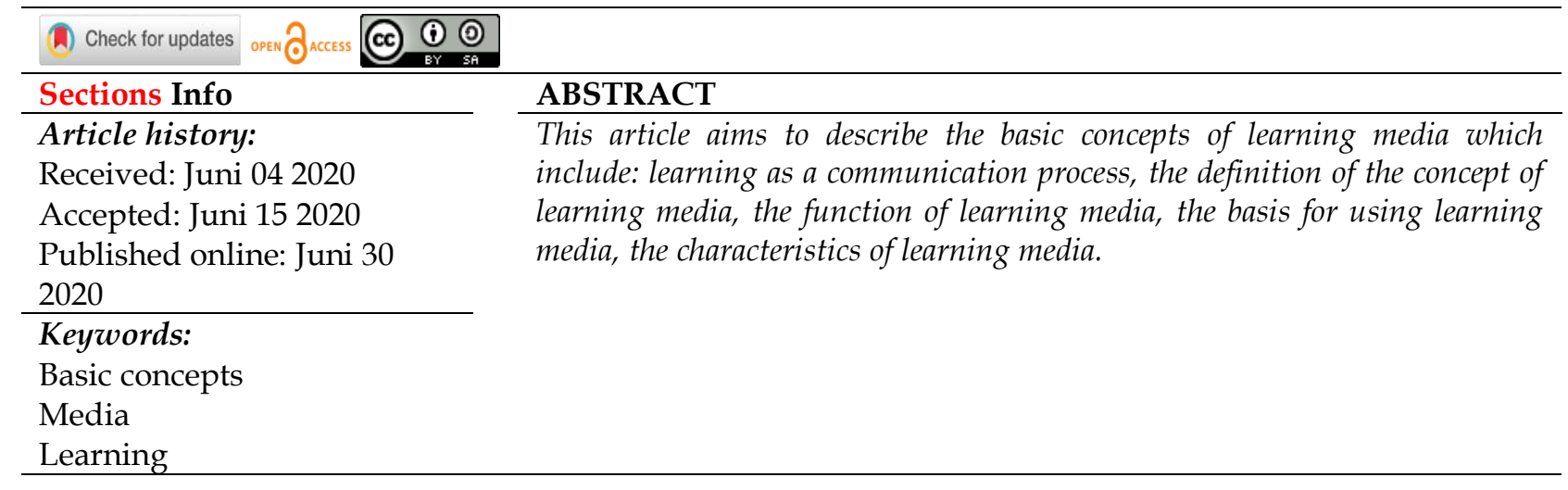

\section{INTRODUCTION}

Kata media memiliki bentuk jamak berupa medium. Media berasal dari bahasa Latin yang mempunyai arti perantara atau pengantar (Mahnun, 2012) Media dapat pula didefinisikan sebagai segala bentuk dan saluran yang digunakan orang untuk menyalurkan pesan atau informasi (Mahnun, 2012). Dalam kegiatan belajar mengajar, media pembelajaran merupakan suatu kebutuhan primer untuk melancarkan pembelajaran(Inah, 2015) Menciptakan situasi belajar yang efektif dan efisien dengan menggerakkan segala sumber belajar (Hermawan, 2017) Dalam hal ini, media pembelajaran sebagai salah satu pendukung yang mendorong proses pembelajaran. Adapun beberapa manfaat media pembelajaran antara lain seperti kegiatan belajar mengajar dapat dilakukan secara mantab, dapat memberikan pengajaran secara ilmiah, dapat menciptakan kedekatan antara penyalur pesan (tenaga pendidik) dengan penerima pesan (peserta didik), serta dapat menyajikan pendidikan secara luas, dapat meningkatkan mutu pendidikan (Mahnun, 2012) Dalam media pembelajaran, tidak lepas dari istilah belajar dan pembelajar.

Tujuan belajar ialah adanya perubahan perilaku pada peserta untuk agar menjadi lebih baik (Sunhaji, 2014). Sedangkan, pembelajaran merupakan proses interaksi antara peserta didik dengan lingkungan, serta mengharapkan terjadi perubahan perilaku yang lebih baik. Memberikan batasan dalam media pembelajaran dapat digunakan untuk merangsang pikiran, perasaan, perhatian, serta kemauan semangat belajar dalam diri peserta didik. Pemilihan media pembelajaran yang tepat oleh seorang pendidik berdasarkan teknik dan langkah-langkah yang benar tentu dapat menyukseskan program belajar agar tercapai perubahan tingkah laku yang diharapkan. Pada kenyataannya banyak tenaga pendidik yang belum memahami serta tidak melakukan teknik dan langkah-langkah pemilihan media pembelajaran yang tepat. Masih banyak para pengajar yang mengandalkan papan tulis sebagai satu-satunya media pembelajaran. 
Oleh karena itu, media pembelajaran merupakan kebutuhan yang tidak dapat dielakkan dalam rangka menyukseskan program belajar peserta didik. Pada hakikatnya media pembelajaran merupakan sebuah komponen pendidikan yang dapat merangsang semangat belanjar peserta didik (Mahnun, 2012). Secara sederhana media pembelajaran merupakan alat peraga yang dapat mempermudah penyampaian pesan dari sumber pesan kepada penerima pesan. Sebagai tenaga pendidik memiliki kekreatifan dan berpikir inovatif merupakan hal media pembelajaran berupa dapat berupa seminar, diskusi, simulasi, karyawisata, studi banding, dan lain sebagainya.yang penting. Menciptakan media pembelajaran yang kreatif dan inovasi dapat meningkatkan mutu pendidikan. Media pembelajaran yang dapat menunjang kegiatan belajar mengajar antara lain power point, video, kaset, audio, slide, film strip, OHP, film, radio, televisi, dan lain sebagainya (Jauhari, 2018) Selain itu, media pembelajaran berupa dapat berupa seminar, diskusi, simulasi, karyawisata, studi banding, dan lain sebagainya.

\section{RESEARCH METHOD}

Kajian dalam penelitian ini menggunakan pendekatan deskriptif kualitatif dengan jenis kajian kepustakaan/library research, data yang didapat mengenai konsep dasar media pembelajaran yang ada, kemudian direduksi diambil kesimpulan berdasarkan pemahaman peneliti terhadap konsep yang sudah ada maupun terdahulu dan wacana ilmiah yang dianalisis secara mendalam terhadap persoalan yang terjadi terkait bidang pendidikan.

\section{RESULTS AND DISCUSSION KONSEP DASAR MEDIA PEMBELAJARAN}

\section{a. Pembelajaran Sebagai Proses Komunikasi}

Guru harus mampu mengembangkan hasil belajar semaksimal mungkin karena hal tersebut adalah tugas dan kewajiban guru untuk menciptakan suatu pembelajaran (Inah, 2015). Agar terangsangnya penciptaan suatu pembelajaran yang lebih efektif dan efisien kegiatan pembelajaran harus didesain dan diperlukan strategi komunikasi yang baik dalam penyampaiannya (Lanani, 2013). Menciptakan suatu pembelajaran sekaligus mengubah pola lama dari teacher-centered menjadi student-centered adalah salah satu kemampuan dari seorang guru (Jauhari, 2018). Proses komunikasi, adalah proses penyampaian pesan dari sumber pesan melalui saluran atau media tertentu ke penerima pesan. Hal tersebut merupakan hakikat dalam sebuah pembelajaran (Lanani, 2013). Komponen-komponen proses komunikasi terdiri dari pesan, sumber pesan, saluran atau media, dan penerima pesan (Inah, 2015). Pesan yang akan dikomunikasikan adalah isi ajaran ataupun didikan yang terdapat dalam kurikulum, guru, siswa, orang lain, penulis buku adalah sumber pesannya, media pembelajaran adalah salurannya, dan pembelajar sebagai penerima pesan. Penafsiran terhadap isi pesan sewaktu-waktu bisa berhasil dan bisa juga gagal oleh karena itu proses dalam komunikasi tidak selamanya berhasil (Mahnun, 2012). Adanya faktor penghambat proses komunikasi yang dikenal dengan istilah barriers dan noises adalah penyebab dari kegagalan proses komunikasi (Nofrion, 2016). Seperti keterbatasan pada daya ingat, cacat pada tubuh, hambatan pada jarak geografis, perbedaan pada gaya belajar, minat, Intelegensi, waktu dan lain-lain adalah salah satu penghambat proses komunikasi. 
Media digunakan untuk belajar hal tersebut media dapat dimanfaatkan sebagai penunjang dalam seorang pelajar, karena untuk mempermudah kegiatan penyampaian informasi adalah tujuan dari pengguna media.

Menurut Harold Lasswell yang dikutip oleh Nofrion, (2016) komponen komunikasi secara umum ada lima yang cukup dikenal dan dipahami secara luas oleh masyarakat yaitu:

1. Sumber informasi (source)

Sumber informasi atau source merupakan seorang individu yang bersangkutan memiliki keinginan untuk melakukan berinteraksi dengan antar individu, berinteraksi antar kelompok suatu organisasi, maupun berinteraksi suatu perusahaan antar individu (Mahnun, 2012).

2. Pesan

Pesan ialah sebuah informasi yang diberikan terhadap pengirim pesan yang akan disampaikan kepada penerima pesan. Selain itu, pesan ialah suatu pesan yang berisi informasi yang mengandung verbal maupun non verbal (Mahnun, 2012).

3. Saluran atau media

Saluran atau lebih akrab dikenal dengan media ialah suatu perangkat pembelajaran yang berfungsi untuk menyalurkan sebuah informasi pembelajaran terhadap peserta didik (Mahnun, 2012).

4. Penerima (receiver)

Penerima yakni orang ataupun sekelompok masyarakat yang memiliki tugas menerima pesan.

5. Efek

Efek merupakan dampak yang diperoleh oleh si penerima pesan sesudah menerima pesan dari penerima pesan. Efek ini tergantung kepada substansi pesan yang diterima. Bisa dalam bentuk bertambahnya pengetahuan dan informasi (Pane \& Darwis Dasopang, 2017).

Adapun beberapa unsur yang dapat dikumpulkan berupa feed back, barriers, dan suatu konteks dalam komunikasi diantaranya sebagai berikut (Nofrion, 2016):

6. Umpan balik (feed back)

Umpan balik lebih akrab dikenal dengan feed back merupakan suatu respons dari penerima pesan yang mampu mempengaruhi si pengirim pesan untuk komunikasi selanjutnya (Pane \& Darwis Dasopang, 2017).

7. Gangguan atau kendala komunikasi (noise/barriers)

Gangguan atapun kendala komunikasi dapat terjadi apabila suatu komponen komunikasi tidak dapat berjalan secara efektif.

Dengan demikian, dapat disimpulkan bahwa ada tujuh komponen komunikasi diantaranya: 1) sumber informasi, 2) penerima informasi, 3) media informasi, 4) informasi, 5) efek, 6) umpan balik/ feed back, 7) gangguan/ barrier. Salah satu naluri alamiah manusia adalah berhubungan dengan manusia lain, membentuk hubungan dan mengelompok (Nofrion, 2016). Suatu kelompok baik besar maupun kecil, adalah kumpulan beberapa orang yang memiliki dasar dan filosofi serta tujuan yang sama serta memiliki aturan-aturan bersama yang dipatuhi oleh semua anggota kelompok.

\section{b. Pengertian Media Pembelajaran}


Media ialah jembatan yang bertugas untuk menyalurkan informasi terhadap pihak yang bertugas sebagai penerima, misalnya media televisi, media komputer, serta media lain sebagainya (Jauhari, 2018). Pembelajaran yakni suatu kegiatan berkomunikasi yang bertujuan untuk menyampaikan pesan dari pusat pesan dengan menggunakan saluran atau media, dan penerimaan pesan ini adalah komponen komunikasi (Jauhari, 2018). Media pembelajaran ini merupakan segala yang berhubungan dengan alat, lingkungan dan segala jenis kegiatan yang diposisikan untuk menambah pengetahuan, menambah keterampilan pada setiap manusia yang memanfaatkannya dan mengubah sikap (Sanjaya, 2012).

Menurut para ahli:

1. Rossi dan Breidle (1966)

Media pembelajaran ialah segala sesuatu yang bermanfaat untuk meningkatkan pembelajaran menjadi lebih, seperti media audio-visual berupa televisi, media cetak berupa koran, media cetak berupa majalah, media cetak berupa buku, media audio berupa radio, serta beberapa media lain sebagainya. Rossi dan Breidle berpendapat bahwa alat sejenis media komunikasi berupa televisi dan radio apabila diatur dan digunakan untuk pendidikan, maka bisa disebut dengan media pembelajaran (Sanjaya, 2012).

2. Miarso (1984)

Media pendidikan atau lebih akrab dikenal dengan media pembelajaran ialah sebuah wadah yang dapat dipakai untuk mendatangkan perhatian, pemikiran, feeling (perasaan), serta ketertarikan peserta didik untuk merangsang motivasi belajar (Rusydiyah, 2014).

3. Ibrahim dkk (2004)

Media pendidikan lebih akrab dikenal dengan media pembelajaran ialah segala sesuatu yang berfungsi untuk mengirim pesan agar mempengaruhi motivasi minat belajar peserta didik untuk mencapai hasil belajar yang maksimal. Contohnya: bagan, gambar, film, model, vidio, komputer dan lain-lain (Rusydiyah, 2014).

\section{c. Fungsi Konsep Dasar Media Pembelajaran}

Media menjadi salah satu bagian komponen system pembelajaran, yang mempunyai fungsi dan peran yang sangat penting bagi kelangsungan pembelajaran (Jauhari, 2018). Dengan begitu media mempunyai posisi yang strategis sebagai bagian integral dari pembelajaran. Integral disini mengandung arti bahwa media itu merupakan bagian yang tidak terpisahkan dari pembelajaran. Maka jika tanpa adanya media, pembelajaran tidak akan pernah terjadi (Rusydiyah, 2014). Sebagai komponen sistem pembelajaran, maka media pembelajaran mempunyai fungsi yang berbeda dari fungsi komponen-komponen lainnya, yaitu sebagai komponen yang berisi pesan pembelajaran untuk disampaikan kepada peserta didik. Pada proses penyampaian pesan tersebut biasanya sering terjadi gangguan yang mengakibatkan pesan pembelajaran tidak diterima atau dicerna oleh peserta didik apa yang dimaksudkan oleh pendidik (Wahidin \& Ahmad, 2018). Gangguan-gangguan komunikasi antara penyampai pesan dengan peserta didik ini mungkin sebagian besar disebabkan oleh beberapa hal, yaitu: verbalisme, salah menafsirkan, perhatian ganda, pembentukan persepsi tidak bermakna, dan kondisi lingkungan yang tidak menunjang (Wahidin \& Ahmad, 2018). Terdapat kunci pemecahan masalah-masalah yang terkait dengan 
gangguan proses pemyampaian pesan pembelajaran ini terletak pada media yang dipakai dalam proes tersebut. Secara garis besar fungsi media adalah (Jauhari, 2018):

1. Membangkitkan minat maupun motivasi.

2. Mengaktifkan anak didik (murid) dalam proses kegiatan belajar mengajar ketika berlangsung.

3. Mengefekfifkan motivasi minat belajar anak didik (murid).

4. Memikat perhatian siswa maupun siswi.

5. Membantu meminimalisir adanya ruang, waktu, dan ukuran.

6. Menghindari terjadinya verbalisme.

Fungsi dari media pembelajaran dijelaskan oleh pendapat lain bahwa telah diamati berasal dari dua aspek yakni sebuah proses pendidikan (pembelajaran) dapat diartikan proses kegiatan berinteraksi serta komunikasi antar anak didik atau peseta didik. Informasi yang berasal dari sumber (guru) kepada penerima (siswa) juga termasuk fungsi dari media pembelajaran, maka dapat ditinjau bahwa komunikasi adalah proses dari pembelajaran.

Terdapat juga beberapa fungsi media pendidikan (pembelajaran) diantaranya:

1. Fungsi media pembelajaran sebagai sumber belajar

Dapat diketahui bahwa media pendidikan atau lebih akrab dikenal sebagai sumber belajar. Sumber belajar yang memiliki makna tersirat artinya ketangkasan atau keaktifan yaitu memiliki tugas sebagai penyalur, penyamai, penghubung, dan lain sebagainya. Secara garis besar bahwa sumber belajar adalah fungsi utama dari media pembelajaran selain itu terdapat fungsi-fungsi lain-lainnya (Adam \& Syastra, 2015).

2. Media pembelajaran sebagai fungsi semantik

Fungsi semantik ini menambah arti kata memiliki bermakna serta dapat dipahami oleh anak didik. Kata dan bahasa tersebut seperti lambang dari isi keyakinan pikiran dan perasaan (Adam \& Syastra, 2015).

3. Media pembelajaran sebagai fungsi manipulatif

Dasar dari fungsi berjenis manipulatif ini terdapat dalam ciri-ciri umum seperti terletak pada kemampuan media pendidikan untuk merekam, kemampuan untuk melestarikan, kemampuan untuk merekonstruksikan, kemampuan untuk menyimpan, dan kemampuan untuk mentransportasi suatu peristiwa atau objek. Dengan berdasarkan karakteristik yang dimiliki oleh media untuk menjalankan perannya sesuai dengan fungsinya, maka media pendidikan (pembelajaran) memiliki dua kemampuan berupa dapat meminimalisir batas antara ruang dan waktu, serta memiliki kemampuan untuk dapat mengatasi keterbatasan inderawi (Adam \& Syastra, 2015).

Dari uraian di atas dapat kita simpulkan bahwa media pembelajaran dapat berfungsi sebagai sumber belajar yakni media yang dapat digunakan sebagai sumber ilmu pengetahuan, berfungsi semantik atau pemaknaan/pemberian makna serta fungsi manipulatif yakni yakni memanipulasi objek dengan tujuan memudahkan peserta didik memahami objek tersebut tanpa harus medatangkan objek asli karena keterbatasan ruang dan waktu

\section{d. Dasar Penggunaan Konsep Media Pembelajaran}


Peranan media pendidikan atau lebih familiar dengan media pembelajaran dikatakan sangat penting dalam suatu proses kegiatan belajar dan kegiatan mengajar. Karena, sebagai calon guru dapat mengetahui segala sesuatu media yang dipersiapkan untuk proses pembelajaran. Guru dapat menggunakan film televisi, atau berupa gambar sebagai bahan media untuk memberikan informasi yang tepat, jelas, dan sesuai kepada siswa di sekolah. Dengan menggunakan media pembelajaran, kegiatan belajar biasanya bersifat abstrak bisa menjadi lebih kongret (Lanani, 2013). Menurut Kemp dan Dayton (1985) yan dikutip oleh (Sanjaya, 2012), ada beberapa konstribusi pada dasar penggunaan media pembelajaran yaitu:

1. Proses pembelajaran menjadi tertarik.

Dengan menggunakan media pembelajaran akan menjadikan pembelajaran lebih diminati oleh peserta didik. Suatu pembelajaran yang menggunakan media dalam penyampaiannya akan lebih digandrungi oleh siswa. Hal ini dikarenakan menggunakan media pembelajaran, peserta diidk akan lebih mudah dalam menangkap informasi pembelajaran melalui media yang disediakan oleh tenaga pendidik (Sunhaji, 2014).

2. Kualitas pembelajaran dapat ditingkatkan.

Adanya peningkatan hasil kualitas apabila integritas pengelolaan sebuah kata dan sebuah gambar yang akan dijadikan media pembelajaran dapat memberikan komunikasi titik bagian ilmu pengetahuan yang dapat terorganisir dengan spesifik dan jelas dalam penyampaiannya (Sunhaji, 2014).

3. Penyampaian isi pesan pembelajaran dapat lebih berstandar.

Setiap guru pasti memiliki ciri dalam memahami tafsir isi suatu mata pelajaran dengan pemahaman yang beragam, namun adanya menggunakan media pembelajaran dapat menjadikan berbagai cara memahami hasil dari tafsiran suatu mata pelajaran. Media pembelajaran dapat mengurangi perbedaan dalam memahami tafsir isi mata pelajaran oleh seorang guru. Hal ini akan menimalisir hasil pemahaman yang berbeda dari seorang guru, sehingga informasi yang akan tersampaikan terhadap peserta didik lebih mudah dipahami (Falahuddin, 2014).

4. Waktu pelaksanaan pembelajaran dapat dipersingkat.

Adanya alokasi jangka waktu proses pembelajaran yang diperlukan dapat diperpendek dengan menggunakan media, sehingga alokasi waktu pembelajaran dapat dipersingkat untuk bisa mentransferkan isi pesan dari pelajaran walaupun memakan jumlah yang tidak sedikit, serta peserta didik dapat menyerapnya (Falahuddin, 2014).

Biasanya, kecenderungan anak didik dalam menggunakan media sangat tinggi khususnya dalam meningkatkan keterlibatan belajar anak didik. Dapat mendorong terbentuknya suasana belajar komunitas yang kolaboratif dan mendorong terciptanya belajar mengajar secara aktif (Falahuddin, 2014). Secara rinci, menurut Azhari, (2015) menjelaskan beberapa hal penting dalam penggunaan media pembelajaran yakni:

1. Meningkatkan Mutu Pembelajaran

Adapun faktor penting yang dapat membentuk pendidikan menjadi berkualitas yang baik yaitu memperhatikan kemampuan tenaga pendidik 
dalam melakukan kegiatan belajar mengajar. Sebagai seorang tenaga pendidik harus siap mempunyai rancangan dan berbakat dalam keterampilan untuk dapat memanfaatkan dan mengelolah media pembelajaran sebagai cara dalam mengasah kemampuan minat, bakat, serta motivasi untuk belajar peserta didik (Azhari, 2015). Seperti halnya Rapibdhe menjelaskan tentang kemampuan peserta didik terhadap akibat aktivitas suatu pembelajaran diantaranya:

a. 0,1 berasal dari kemampuan membaca.

b. 0,2 berasal dari kemampuan mendengar.

c. 0,3 berasal dari kemampuan mengamati (melihat).

d. 0,5 berasal dari kemampuan mengamati (melihat) dan mendengar.

e. 0,7 berasal dari kemampuan menulis dan mengucapkan (berbicara).

f. 0,9 berasal dari kemampuan mengucapkan (berbicara) dan melakukan.

Jadi, dari perbedaan presentase pemahaman yang dilihat memlai beberapa indra maka dapat dijelaskan bahwa rancangan media dapat diarahkan untuk mendorong optimalisasi proses belajar dengan pemanfaatan media pembelajaran yang sesuai dengan aktivitas diatas.

1. Adanya Tuntutan Paradigma Baru

Paradigma baru atau lebih akran dikenal dengan tuntutan perubahan baru dalam pendidikan menjadikan seorang tenaga pengajar (guru) harus memiliki peran tidak sekedar mentransfer keilmuannya (pengetahuan) kepada anak didik atau tidak sekedar bertugas memberikan sebuah materi, namun juga diwajibkan menjadi sebuah fasilitator yang memfasilitasi peserta didiknya untuk menggali kemampuannya dengan semaksimal mungkin, seorang tenaga pengajar bertugas sebagaiperancang pembelajaran, bahkan sebagai manajer saat dalam kelas. Sebagai anak didik juga bukan hanya sekedar menerima pengetahuan atau menguasai isi pelajaran yang didapat melainkan juga harus menerapkan, menganalisis, mengevaluasi sesuatu yang diberikan untuk dunia. Seperti halnya prinsip pembelajaran menurut Merril yang mencangkup demontrasi, mengaplikasikan, sebuah prinsip yang berbasis pada penugasan, serta sebuah aktivasi yang diperhatikan sebagai acuan untuk menggali keilmuan sesuai kondisi tindakan.

2. Mencukupi Kebutuhan Pasar

Menggunakan media pendidikan atau media pembelajaran disesuaikan untuk memenuhi tuntutan kebutuhan pasar. Hal ini diwajibkan bagi lulusan menjadi seorang sarjana pendidikan dapat berenang pada era industri 4.0 ini.

Pengkajian keilmuan pada seorang sarjana pendidikan dituntut dapat paham pada era revolusi industri 4.0 Sehingga, hal ini dapat mencetak seorang sarjana pendidikan yang sangat mutakhir dalam keilmuan pada bidang pendidikan.

3. Memperhatikan Visi Pendidikan Global

Era revolusi industri 4.0 telah mengubah dunia global secara signifikan. Manusia dimanja dengan kelebihan teknologi yang sangat berkembang amat pesat. Ruang lingkup pendidikan sanagt dipengaruhi oleh perkembangan industri 4.0 ini. Dapat dilihat dari beberapa model pendidikan berupa home schooling, model belajar mandiri, serta pembelajaran berbasis jarak jauh kini menjadi trend model pembelajaran pada era revolusi industri 4.0. 


\section{e. Ciri-Ciri Media Dalam Pembelajaran}

Adapun ciri-ciri media pendidikan atau media pembelajaran secara umum adalah sebagai berikut (Arsyad, 2009):

1. Media pembelajaran atau media pendidikan mempunyai arti secara fisik yang lebih familiar dengan hardware atau wadah, alat, maupun benda yang dapat dirasa oleh panca indera manusia (Adam \& Syastra, 2015).

2. Media pembelajaran mempunyai arti secara non fisik yang lebih familiar dengan software atau pesan yang disampaikan melalui hardware (Adam \& Syastra, 2015).

3. Media pembelajaran memiliki penekanan terhadap visual serta audio (Wahidin \& Ahmad, 2018).

4. Media pembelajaran juga memiliki arti sebagai alat atau media bantu dalam proses kegiatan pembelajaran (Wahidin \& Ahmad, 2018).

5. Media pembelajaran dapat digunakan dalam kegiatan proses komunikasi serta kegiatan berinteraksi antara guru dengan anak didiknya.

6. Dapat digunakan secara masal contohnya media komunikasi berupa televisi serta radio juga secara perorangan contohnya modul.

Adapun ciri-ciri media pendidikan atau media pembelajaran menurut Gerlach dan Ely yang dikutip oleh Arsyad, (2009) adalah sebagai berikut:

1. Media pembelajaran berciri fiksatif

Ciri media pembelajaran fiksatif mengilustrasikan fungsi media memiliki kemampuan untuk merekam, merekonstruksikan, serta menyimpan sebuah objek berupa fotografi, audio tape, video tape, dan lain sebagainya (Jauhari, 2018).

2. Media pembelajaran berciri manipulatif

Ciri media pembelajaran manipulatif dapat mentransformasikan dari sebuah objek. Awalnya suatu objek dapat membutuhkan waktu yang relatif lama, sehingga dapat dipangkas menjadi beberapa menit dengan teknik time lapse recording (Adam \& Syastra, 2015).

3. Media pembelajaran berciri distributif

Ciri media pembelajaran distributif dapat mentrasformasikan suatu objek melalui ruang. Dalam waktu yang sama objek tersebut dapat disajikan terhadap peserta didik melalui stimulus pengalaman tenaga pendidik (Jauhari, 2018).

\section{CONCLUSIONS}

Secara umum kegiatan pembelajaran ialah proses komunikasi yang melibatkan sumber pesan dengan penerima pesan. Sumber pesan dalam suatu pembelajaran yaitu guru, sedangkan penerima pesan dalam suatu pembelaran ialah peserta didik. Sumber pesan dengan penerima pesan menjalin hubungan simbiosis mutualisme. Artinya pesan yang disampaikan oleh sumber pesan dapat berjalan dengan baik apabila ada peran sebagai penerima pesan. Akan tetapi, dalam komunikasi antara sumber pesan dengan penerima pesan tidak selamanya berjalan dengan baik. Ada kalanya terjadi beberapa kendala yang melibatkan komunikasi menjadi gagal. Sehingga, guru yang berperan sebagai sumber pesan menggunakan media pembelajaran dalam menyampaikan materi pembelajaran. Media pembelajaran dapat mempermudah 
peserta didik dalam menangkap informasi pembelajaran yang disampaikan oleh sumber pesan. Guru diwajibkan untuk mengasah keterampilannya dalam menciptakan media pembelajaran. Tidak selamanya media pembelajaran hanya dapat menggunakan teknologi. Dengan cara memanfaatkan lingkungan sekitar dapat juga menjadi media pembelajaran. Kegiatan belajar mengajar akan lebih menarik apabila media pembelajaran yang digunakan oleh guru dapat memikat hati peserta didik. Sehingga dapat mewujudkan dalam proses pembelajaran membentuk peserta didik yang memiliki antusias dan bersemangat dalam pembelajaran yang berlangsung.

\section{ACKNOWLEDGEMENTS (OPTIONAL)}

Peneliti mengucapkan terima kasih kepada UINSA Surabaya dan IAIM Sinjai, Sinjai atas dukungan dan bantuan terlaksananya hasil penulisan ini.

\section{REFERENCES}

Adam, S., \& Syastra, M. T. (2015). Pemanfaatan Media Pembelajaran Berbasis Teknologi Informasi Bagi Siswa Kelas X SMA Ananda Batam. CBIS Journal, 3 No 2(ISSN 23378794), 78-90.

Arsyad, A. (2009). Media Pembelajaran. Raja Grafindo Persada.

Azhari, A. (2015). Peran Media Pendidikan Dalam Meningkatkan Kemampuan Bahasa Arab Siswa Madrasah. Jurnal Ilmiah Didaktika, 16(1), 43. https://doi.org/10.22373/jid.v16i1.586

Falahuddin, I. (2014). Pemanfaatan Media Dalam Pembelajaran. Jurnal Lingkar Widyaiswara, 1(4), 104-117.

Hermawan, A. (2017). Konsep Belajar Dan Pembelajaran Menurut Al-Ghazali. Qathrunâ, 1(01), 84-98. http://jurnal.uinbanten.ac.id/index.php/qathruna/article/view/247

Inah, E. N. (2015). Peran Komunikasi Dalam Interaksi Suru Dan Siswa. Al-Ta'dib, 8(2), 150-167.

Jauhari, M. I. (2018). Peran Media Pembelajaran dalam Pendidikan Islam. Journal Piwulang, 1(1), 54. https://doi.org/10.32478/ngulang.v1i1.155

Lanani, K. (2013). Belajar Berkomunikasi Dan Komunikasi Untuk Belajar Dalam $\begin{array}{lllll}\text { Pembelajaran Infinity Journal, } & \text { Matematika. }\end{array}$ https://doi.org/10.22460/infinity.v2i1.21

Mahnun, N. (2012). Media Pembelajaran (Kajian terhadap Langkah-langkah Pemilihan Media dan Implementasinya dalam Pembelajaran). An-Nida', 37(1), 27-35.

Nofrion. (2016). Komunikasi Pendidikan. Kencana Prenada Media.

Pane, A., \& Darwis Dasopang, M. (2017). Belajar Dan Pembelajaran. FITRAH:Jurnal Kajian Ilmu-Ilmu Keislaman, 3(2), 333. https:/ / doi.org/10.24952/fitrah.v3i2.945

Rusydiyah, E. F. (2014). Media Pembelajaran. UIN Sunan Ampel Press.

Sanjaya, W. (2012). Media Komunikasi Pembelajaran. Kencana Prenada Media Group.

Sunhaji, S. (2014). Konsep Manajemen Kelas Dan Implikasinya Dalam Pembelajaran. Jurnal Kependidikan, 2(2), 30-46. https:// doi.org/10.24090/jk.v2i2.551

Wahidin, U., \& Ahmad, S. (2018). Media Pendidikan Dalam Perpekstif Pendidikan 
Islam. Jurnal Pendidikan Islam, 07(1), 23-46. https://doi.org/10.30868/EI.V7

Author (s) :

*Juhaeni, M.Pd.I (Corresponding Author)

Fakultas Tarbiyah dan Keguruan,

UIN Sunan Ampel Surabaya, Indonesia

Jl. Ahmad Yani No 117 Surabaya

Email: juhaeni@uinsby.ac.id

\section{Safaruddin, M.Pd.I}

Fakultas Tarbiyah dan Ilmu Keguruan IAIM Sinjai, Indonesia Jl. Sultan Hasanuddin No 20 Balangnipa Sinjai, Indonesia

Email: sarthi339@gmail.com

\section{R Nurhayati, M.Pd.I}

Fakultas Tarbiyah dan Ilmu Keguruan IAIM Sinjai, Indonesia

Jl. Sultan Hasanuddin No 20 Balangnipa Sinjai, Indonesia

Email : rnurhayati1984@gmail.com

\section{Aulia Nur Tanzila}

Fakultas Tarbiyah dan Keguruan,

UIN Sunan Ampel Surabaya, Indonesia

Jl. Ahmad Yani No 117 Surabaya 